\title{
Hobbes i Grocjusz o wojnie i przemocy w stosunkach międzynarodowych
}

DOI 10.35757/CIV.2015.17.04

W artykule omówimy i porównamy dwie filozoficzne tradycje stosunków międzynarodowych pod katem ich podejścia do wojny i przemocy. Pierwsza to tradycja realizmu politycznego (Hobbesowska), a druga to tradycja szkoły angielskiej (Grocjuszowska). Każde $z$ tych ujęć inaczej rozumie rolę przemocy i wojny w stosunkach międzynarodowych. Przemoc $z$ punktu widzenia realizmu politycznego to część anarchistycznych relacji stosunków międzynarodowych oraz ewentualny środek do realizacji własnych interesów politycznych. Z kolei teoria społeczności międzynarodowej będzie mówiła o przemocy jako o czynniku, który należy minimalizować poprzez dążenie do takiego stanu, który będzie premiował pokojowa współpracę. Przemoc ma tu zatem dwa oblicza: bezprawne, gdy wykracza poza porządek współpracy, albo uprawomocnione, gdy jest zwiąana ze sprawiedliwościa wyrównawcza - wtedy strony używajace siły powinny stosować się do reguły interwencji humanitarnej i wojny sprawiedliwej.

Przyjrzymy się tym dwóm podejściom, starając się pokazać, że podejście Thomasa Hobbesa do stosunków międzynarodowych moż-

Rafał Wonicki - doktor, pracuje jako adiunkt w Zakładzie Filozofii Polityki Instytutu Filozofii Uniwersytetu Warszawskiego. 
na wpisać w perspektywę rozważań szkoły angielskiej, tym samym uwzględniając istotna rolę normatywnych idei oraz regulatywna rolę wojny sprawiedliwej $\mathrm{w}$ prawie międzynarodowym i w praktyce politycznej. Porównując elementy teorii Hobbesa $z$ elementami teorii Hugona Grocjusza, wykażemy, że bezprawna i bezgraniczna przemoc stanu natury po utworzeniu się państw jest łagodzona w stosunkach międzynarodowych za sprawa wzajemnych korzyści płynacych ze współpracy - również w kwestii przestrzegania reguł prowadzenia wojny. W celu udowodnienia naszej tezy zaczniemy od przedstawienia Hobbesa opisu stanu natury i jego podejścia do wojny, następnie na przykładzie Grocjusza idei społeczności międzynarodowej omówimy zalety podejścia współczesnej szkoły angielskiej do stosunków międzynarodowych rozumianych jako kooperacja państw w ramach społeczności międzynarodowej, aby w kolejnym kroku zastanowić się, na ile interpretacja Hobbesa w świetle założeń szkoły angielskiej jest uprawniona, i ostatecznie przedstawić wnioski płynące $z$ całej analizy.

\section{Hobbesa stan natury jako stan wojny}

Zdaniem Hobbesa, stan natury jest stanem wojny, w którym ludzie, rywalizując między sobą, walczą o przeżycie. W stanie tym nie ma miejsca na trwałą współpracę ani na cieszenie się owocami swojej pracy ze względu na to, że sa one niepewne i zagrożone zawłaszczeniem ich przez innych. Co więcej, nie ma tam

miejsca na obrabiane ziemi ani żeglowanie, nie ma bowiem żadnego pożytku z dóbr, które moga być przywiezione morzem; nie ma wygodnego budownictwa; nie ma narzędzi do poruszania i przesuwania rzeczy, co wymaga wiele siły; nie ma wiedzy o powierzchni ziemi ani obliczania czasu, ani sztuki, ani umiejętności, ani sztuki słowa, ani społeczności. A co najgorsze, jest bezustanny strach i niebezpieczeństwo gwałtownej smierci. I życie człowieka jest samotne, biedne, bez słońca, zwierzęce i krótkie"1.

T. Hobbes, Lewiatan, czyli Materia, forma i władza państwa kościelnego $i$ świeckiego, przekład Cz. Znamierowski, Państwowe Wydawnictwo Naukowe, Kraków 1954, s. 110. 
W stanie natury, w którym nie ma trwałych praw i nie rządza żadne zasady etyczne poza instynktami i afektami, trwa wojna wszystkich ze wszystkimi. Hobbes nie ogranicza zarazem rozumienia wojny jedynie do faktycznej walki i aktów przemocy. Rozumie on wojnę raczej jako stan nieustannej gotowości do przemocy wynikającej $z$ natury człowieka oraz braku sił mogacych ludzi przed nia powstrzymać. Ludzie w stanie natury sa, zdaniem Hobbesa, równi i żyją zdani na łaskę swych własnych zasobów oraz umiejętności, które sa jedynym zabezpieczeniem i gwarantem ich istnienia. W owym pierwotnym stanie wojny, jako stanie naturalnym, nie obowiąuja kategorie dobra i zła, sprawiedliwości i niesprawiedliwości. Słuszne jest to, co służy człowiekowi do przetrwania. Wojna zatem nie potrzebuje w stanie natury żadnych usprawiedliwień, po prostu jest powszechna, stała możliwością. Sytuacja ta zmienia się w momencie zawarcia umowy i zawiązania stanu państwowego. Wtedy to ludzie zrzekaja się części swych uprawnień, w tym uprawnienia do wszczynania wojen na rzecz posłuszeństwa suwerenowi. Po utworzeniu państwa jedynie suweren, dla którego wojna może być sposobem realizacji celów, do których został przez ludzi powołany - do zaprowadzenia pokoju, do poprawy sytuacji państwa i żyjacych w nim ludzi - ma prawo używania przemocy i wypowiadania wojen. Tym samym stan wojny między ludźmi w stanie natury przechodzi w stan rywalizacji o stanowiska, pozycje i zasoby wewnątrz państwa między obywatelami a jedynymi miejscami, gdzie przemoc stanu natury nadal ma miejsce, jest relacja między obywatelami a suwerenem oraz relacja między suwerennymi państwami.

Tak więc wejście w stan państwowy przez zawarcie umowy społecznej, w której dochodzi do ustanowienia władzy i zrzeczenia się samowolnych działań $z$ użyciem przemocy, przynosi dopiero moralny ład i polityczne bezpieczeństwo - prawo i moralność moga obowiązywać, ponieważ suweren dysponuje siłą, dzięki której potrafi egzekwować sankcje i kary za łamanie prawa przez obywateli. Ludzie stają się obywatelami podległymi suwerenowi, na którego 
scedowali swoje prawa w imię ochrony ich życia. Jednak, jak sygnalizowaliśmy wyżej, po wyłonieniu się suwerennych państw stan natury jako stan wojny wciąż między nimi istnieje. Mimo wszystko wojna każdego z każdym w stanie natury różni się od stanu wojny między suwerennymi państwami. W tym drugim przypadku działania wojenne oraz gotowość do walki wynikaja z obowiąku ochrony życia, mienia i pracy obywateli. Gdy suweren wypowiada wojnę, to zdaniem Hobbesa, musi on mieć ważne ku temu powody. Takimi powodami sa obrona państwa, pokoju i bezpieczeństwa poddanych. To interes państwa lub, jak moglibyśmy powiedzieć za Machiavellim, racja stanu jest dopiero dla Hobbesa właściwym powodem użycia przemocy i wszczęcia wojny.

$\mathrm{Na}$ podstawie powyższego opisu można powiedzieć, że wojna w teorii Hobbesa ma na celu przede wszystkim zabezpieczenie istnienia państwa, a więc przede wszystkim może być rozumiana jako wojna obronna przed agresja i napaścią armii innych państw. W celu spełnienia tego wymogu bezpieczeństwa Hobbesowi potrzebna jest silna władza suwerenna, stojaca na straży porządku wewnętrznego i zewnętrznego, która dzięki uznanym środkom przymusu - policji wewnattrz kraju i armii na zewnątrz - mogłaby zapewnić obywatelom warunki do spokojnego życia - rozumianego tutaj głównie jako biologiczne przeżycie. Jak mówi Hobbes:

Jedyną droga do tego, żeby ustanowić taką moc nad ogółem ludzi, która by była zdolna bronić ich od napaści obcych i od krzywdy, jakie sobie czynia wzajemnie, i która by przez to dawała im takie bezpieczeństwo, iżby swoim własnym staraniem i płodami ziemi mogli się wyżywić i żyć w zadowoleniu - otóż jedyna taka droga jest przenieść cała ich moc i siłe na jednego człowieka albo na zgromadzenie ludzi, które by mogło większościa głosów sprowadzić indywidualna wolę ich wszystkich do jednej woli $[\ldots]$. To jest czymś więcej niż zgoda czy zezwoleniem, to jest realna jedność wszystkich w jednej i tej samej osobie, powstała na mocy ugody każdego człowieka $z$ każdym innym tak, jak gdyby każdy człowiek powiedział każdemu innemu: daje upoważnienie i przekazuje moje uprawnienia do rzadzenia moja osoba temu oto człowiekowi albo temu zgromadzeniu, pod tym warunkiem, że $i$ ty przekażesz mu swoje 
uprawnienia $i$ upoważnisz go do wszystkich jego działań $w$ sposób podobny. Gdy to się stanie, wielość ludzi, zjednoczonych w jedną osobę, nazywa się państwem².

Państwo, choć jest więc tworem czysto ludzkim - tworem sztucznym (Lewiatanem) - to jest zarazem jedynym sposobem, w jaki ludzie moga zwiększyć swe szanse na przetrwanie i zapewnić sobie bezpieczeństwo, również przed wrogiem zewnętrznym. Powstanie państwa i zabezpieczającej go silnej władzy pozwala zarazem ujawnić i strzec praw natury. Hobbes wymienia osiemnaście takich praw, które powinny być przestrzegane, jeśli ludzie chca żyć w harmonii. Prawa te maja na celu wprowadzenie lub utrzymanie pokoju w państwie i w zasadzie można je również uznać za reguły, które powinny obowiązywać $\mathrm{w}$ relacjach między państwami. Nie będziemy tu wyliczać ich wszystkich, wskażemy jedynie na kilka ważnych $z$ perspektywy stosunków międzynarodowych ${ }^{3}$. Hobbes twierdzi więc, że 1. należy dążyć do pokoju, a gdy to nie jest możliwe, to należy bronić się wszelkimi dostępnymi środkami; 2. należy być w gotowości do rezygnacji ze wszystkich rzeczy, które sa konieczne do zapewnienia pokoju; 3. należy dotrzymywać zawieranych umów; 4. należy być uprzejmym, 5. a także wybaczać; 10. należy uznawać się za równych $z$ natury ${ }^{4}$. Przestrzeganie tych praw prowadzi do harmonijnego współżycia. Gdy zastosujemy zaś te prawa do relacji między państwami, okazuje się, że suwerenne państwa powinny dążyć do pokoju, dotrzymywać umów zawieranych między sobą, a także dysponować akceptowalnymi procedurami na czas wojny i czas pokoju.

Oczywiście treść owych praw jest, zdaniem Hobbesa, jedyna filozofia moralną. Jest wiedza o tym, co jest dobre i sprawiedliwe, a co takie nie jest. Możliwość zabezpieczania tych praw w ramach

\footnotetext{
2 Ibidem, s. 151.

3 Numeracja praw natury odzwierciedla numerację Hobbesa.

4 Zob. T. Hobbes, Elementy filozofii, t. 2, przekład Cz. Znamierowski, Państwowe Wydawnictwo Naukowe 1956, s. 217-256; Idem, Lewiatan..., s. 114-138. Prawa te zostały nieznacznie zmodyfikowane w swojej gramatycznej formie, aby dopasować je do całości zdania, nie zmieniło to jednak ich sensu.
} 
jego teorii uzyskuje się dzięki zawarciu umowy o scedowanie władzy na suwerena i utworzeniu państwa. Jak zatem można stosować te prawa $\mathrm{w}$ stosunkach międzynarodowych, gdy państwo światowe nie istnieje? $\mathrm{Na}$ to pytanie będzie się właśnie starała odpowiedzieć szkoła angielska.

\section{Szkoła angielska i Grocjusz}

Dla przedstawicieli szkoły angielskiej, wykorzystujących podejście Grocjusza do analizy relacji międzynarodowych, brak nadrzędnego suwerena $\mathrm{w}$ tych relacjach nie powoduje takich samych reperkusji jak jego brak w stosunkach między ludźmi. Wynika to, ich zdaniem, $z$ faktu, że sa to różne porządki ${ }^{5}$. Brak zabezpieczenia prawa między ludźmi w stanie natury skutkuje większym prawdopodobieństwem wojny niż stan, w którym istnieja suwerenne państwa. Widza oni zatem ułomność stosowanej przez Hobbesa analogii między człowiekiem i państwem. Takie podejście otwiera możliwość interpretacji opisu Hobbesa relacji międzynarodowych jako stanu anarchii przez pryzmat założeń teorii Grocjusza o istnieniu kooperującej społeczności międzynarodowej ${ }^{6}$. Wspólne interesy państw okazują się czynnikiem utrwalającym normy postępowania między nimi w taki sposób, że zmniejsza się prawdopodobieństwo wojen, a także reguluje się ich przebieg, gdy te wybuchaja, zgodnie $z$ zasadami doktryny wojny sprawiedliwej. Szkoła angielska uznaje więc, że w celu utrzymania pokoju między suwerenami, również na gruncie teorii Hobbesa, niezbędne jest przestrzeganie wspólnych zasad pokojowej koegzystencji państw.

Aby tego dowieść, szkoła angielska w swoich rozważaniach nad wojna i kooperacja państw czyta Hobbesa przez grocjuszowskie okulary. Filozof ten w swoich dziełach poszukując równowagi mię-

\footnotetext{
5 M.C. Williams, Hobbes and International Relations. A Reconsideration, „International Organization" 1996, t. 50, nr 2, s. 227.

${ }_{6}$ Zob. H. Grocjusz, O prawie wojny i pokoju, przekład R. Bierzanek, Państwowe Wydawnictwo Naukowe 1957.
} 
dzy suwerennościa państwowa a wymogami prawa natury, odrzucał ideę racji stanu jako podstawy, która kieruja się państwa w swoim postępowaniu. Jedna $z$ przesłanek podbudowujaca to rozumowanie jest odmienne od Hobbesowskiego postrzeganie natury ludzkiej nie jako egoistycznej i złej, ale jako już uspołecznionej i posiadającej appetitus societatis. Ludzie maja zatem, jego zdaniem, naturalna skłonność do stowarzyszania się i pokojowego współżycia. Dlatego też Grocjusz może napisać, że:

[p]odobnie jak prawa każdego państwa maja na względzie pożytek tego państwa, tak też mogły powstać pewne prawa w stosunkach międzynarodowych, $[\ldots]$ na podstawie porozumienia państw. I w rzeczywistości powstały prawa, które mają na względzie pożytek nie pojedynczych społeczności (coetus), ale pożytek owej wielkiej powszechności (universitas) ${ }^{7}$.

Swoje rozważania o społeczności międzynarodowej Grocjusz umocowuje i osadza w antropologicznej koncepcji człowieka oraz moralnej idei dobra, wskazując na konieczność współpracy między państwami. Jak pisze:

[...] Nie ma państwa tak silnego, które by nigdy nie potrzebowało pomocy od innych, znajdujących się poza jego granicami, czy to dla prowadzenia handlu, czy też dla powstrzymywania sił zbrojnych obcych narodów, zjednoczonych przeciwko temu państwu. Dlatego widzimy, że nawet bardziej potężne narody i królowie poszukuja przymierzy. Nie miałyby one żadnego znaczenia, gdyby przyjąć poglądy osób, które zamykaja prawo w granicach poszczególnych państw ${ }^{8}$.

Grocjusz uznaje również, że prawo narodów to zbiór określonych zasad organizujacych narody i ich wzajemne relacje. Jego zdaniem, źródłem prawa narodów jest prawo naturalne, które jest możliwe do odkrycia przez rozum ludzki. $Z$ kolei podstawowym powodem, dla którego państwa moga i powinny działać zgodnie $z$ prawem międzynarodowym, jest fakt, że ludzie podlegają właśnie prawu naturalnemu, które moga poznać i zrozumieć wszystkie istoty ludz-

8 Ibidem, s. 59. 
kie. Tak rozumiane przez Grocjusza prawo naturalne jest częścia moralności odniesiona do potwierdzonych przez rozum zasad działania między ludźmi.

Zarazem dla Grocjusza jedynie obrona praw naturalnych będacych podstawą wspólnoty typu universitas może usprawiedliwić wojnę i przemoc. Owe podstawowe prawa w stosunkach międzynarodowych, których naruszenie usprawiedliwia wojnę, to: 1. obowiązek dotrzymywania umów; 2. obowiązek wynagradzania szkód; 3. obowiązek nienaruszania cudzej własności; oraz 4. obowiazek ponoszenia kary za popełnione przestępstwa9 ${ }^{9}$ Grocjusz uznał, że ich obrona jest jedynym dopuszczalnym i sprawiedliwym powodem do wypowiedzenia wojny przez jedno państwo drugiemu. Jak mówi: „Nie ma niczego wśród pierwszych zasad natury, co by pozostawało w sprzeczności $z$ wojna, a nawet wszystko raczej sprzyja wojnie" 10 . Wojna jest więc ostatecznym środkiem do zabezpieczenia praw natury albo przywrócenia ich obowiazywania. Zgodne $z$ prawami natury jest nabywanie lub utrzymywanie rzeczy niezbędnych do życia, zachowanie życia oraz własnej integralności cielesnej, a także sam cel wojny, jakim jest pokój. Natura obdarzyła człowieka siła fizyczna aby mógł się on nią posłużyć w celu obrony siebie i swej własności. Zarówno rozum, jak i natura społeczna nie zabraniają więc w teorii Grocjusza przemocy jako takiej, a tylko tej, która stoi w sprzeczności ze społeczeństwem i narusza prawo innych. Również prawo narodów, będące prawem pozytywnym, nie dyskredytuje wojny - dopuszczając ja jako ostateczny i czasem konieczny środek, choć sama wojna przestaje być zdarzeniem, które wymyka się regulacjom i prawom. Wojna zostaje moralnie i prawnie uregulowana i jedynie wojny publiczne i formalne stają się wojnami, które można sprawiedliwie wszczynać

\footnotetext{
9 Zob. R. Tokarczyk, Filozofia prawa $w$ perspektywie prawa natury, Temida 2, Białystok 1997, s. 89.

${ }^{10} \mathrm{H}$. Grocjusz, O prawie wojny i pokoju, s. 106. Nieco wcześniej Grocjusz o wojnie pisze tak: „Możemy zatem powiedzieć, że wojna jest to stan, w jakim znajdują się osoby toczące spór przy użyciu siły" (Grocjusz, O prawie wojny i pokoju, s. 86).
} 
i toczyć ${ }^{11}$. Podobne stanowisko zajmuja przedstawiciele szkoły angielskiej, tacy jak Hedley Bull. Wzorując się na idei Grocjusza społeczności międzynarodowej, próbują oni wskazać na możliwość odczytania Hobbesowskiego stanu wojny w opozycji do tradycji realistycznej, a co za tym idzie, uzasadnić konieczność ograniczenia przemocy w stosunkach międzynarodowych, wzmacniając tym samym akceptację dla założeń wojny sprawiedliwej.

\section{Hobbesa interpretacja szkoły angielskiej}

Aby ocenić trafność argumentów szkoły angielskiej dotyczących reinterpretacji teorii Hobbesa, odwołajmy się do rozważań wspomnianego wcześniej Hedleya Bulla, który stara się dowieść, że przemoc i wojna w stosunkach międzynarodowych moga być ograniczone. W tym celu pokazuje on, że nawet jeśli uznamy Hobbesowska ideę anarchii w stosunkach międzynarodowych, to nie musi ona wykluczać istnienia społeczności państw, ich współpracy i wzajemnego przestrzegania reguł. Bull za Hobbesem podkreśla, że stan natury jest stanem hipotetycznym, pewna heurystyczna sytuacja pomagająca nam zrozumieć konieczność istnienia silnej władzy państwowej. W klasycznej interpretacji modelu Hobbesa nie bylibyśmy jednak w stanie wytłumaczyć, jak to jest możliwe, że państwa wchodza ze soba $\mathrm{w}$ tak złożone struktury interakcji, jakie dziś obserwujemy, i wiążąc się umowami ponadnarodowymi, ceduja część suwerenności na poziom instytucji ponadpaństwowych, takich jak na przykład Unia Europejska. Wszystko to ogranicza przecież realną władzę suwerena. Gdy spojrzymy zarazem na opis stanu natury i na stan naszych współczesnych stosunków międzynarodowych, widzimy, że nie przystaja one do siebie. Hobbes, jak pokazywaliśmy w części pierwszej artykułu, przedstawia stan na-

\footnotetext{
${ }^{11}$ Wojny formalne przebiegaja według prawa narodów i są zgodne $z$ prawem. W przeciwieństwie do wojen nieformalnych, które mimo że mogą mieć słuszna przyczynę, nie sa wspierane autorytetem prawa.
} 
tury jako taki stan, gdzie nie obowiąuja prawa, nie ma gwarancji dotyczacych życia i własności, a ludzie moga w zasadzie zabijać się bezkarnie, ponieważ wygrywa silniejszy. Społeczności nie rozwijaja się, nie akumuluja wiedzy, nie buduja ani nie tworza ${ }^{12}$. Bull twierdzi, że współczesna anarchia międzynarodowa nie przejawia tych cech, a więc, że nie jest anarchia typu Hobbesowskiego. Brak globalnego suwerena nie przeszkadza społeczności międzynarodowej rozwijać wspólnych reguł współdziałania w dziedzinie ekonomicznej, regulacji handlu czy ruchu (na przykład lotniczego ${ }^{13}$. Ze wszystkich cech wymienionych przez Hobbesa zostaje dziś już tylko jego zdaniem stała gotowość państw do wojny, ale i ona sama została poddana licznym ograniczeniom, których państwa co do zasady staraja się przestrzegać (do tych ograniczeń należy na przykład zasadny powód rozpoczęcia wojny, a także określony sposób jej prowadzenia, jak choćby nieatakowanie cywilów) ${ }^{14}$.

Kolejny argument przytaczany przez Bulla ma za zadanie przekonać nas, że w dzisiejszym świecie źródłem porządku w stosunkach międzynarodowych nie jest tylko strach przed przemoca. Państwa współpracują ze sobą również ze względu na korzyści, jakie uzyskuja $z$ takiej współpracy. Przedstawiciele szkoły angielskiej, wskazując na historyczne przykłady popierajace taką tezę, chca pokazać przekraczanie porządku opartego na ontologii suwerennych państw i równowadze sił między nimi w kierunku idei dobrowolnej wzajemnej kooperacji. W tej perspektywie przemoc w postaci groźby wojny czy terroryzmu nie jest już jedynym punktem odniesienia dla zrozumienia relacji między państwami. Podmioty nie sa opisywane psychologicznie jako $z$ natury sobie wrogie albo racjonalnie używajace przemocy jako narzędzia politycznego ${ }^{15}$. Natura przemocy bywa oczywiście różna, ale w strukturze społeczności międzyna-

\footnotetext{
${ }_{12}$ T. Hobbes, Lewiatan..., s. 110.

${ }^{13}$ H. Bull, The Anarchical Society. A Study of Order in World Politics, wyd. 2, Macmillan, London 1995, s. 44-50.

${ }^{14}$ Zob. np. M. Walzer, Wojny sprawiedliwe i niesprawiedliwe, przekład M. Szczubiałka, Wydawnictwo Naukowe PWN, Warszawa 2010.

${ }^{15}$ Zob. np. koncepcja Clausewitza w: C.V. Clausewitz, O wojnie, przekład A. Ciechowicz, L. Koc, F. Schoener, Wydawnictwo Test, Lublin 1995.
} 
rodowej jest ona ograniczana poprzez sieć zależności i regulacji, a sięganie do niej nie odbywa się dziś w sposób tak prosty i uznany za naturalny, jak to miało miejsce $\mathrm{w}$ historii wcześniej ${ }^{16}$.

W końcu Bull wskazuje na to, że sama analogia między jednostka a państwem, która możemy odnaleźć u Hobbesa, jest zawodna. Państwa nie musza tworzyć jakiegoś bytu ponadnarodowego gwarantującego pokój, ponieważ nie są w sytuacji jednostek, które $z$ konieczności musza się łączyć ze sobą w większe grupy, aby przeżyć. Państwa nie sa również co do zasady równe, tak jak ma to miejsce, zdaniem Hobbesa, w przypadku ludzi. Ludzie o różnej sile i możliwościach moga być dla siebie tak samo groźni, ale państwa już nie. Zatem w państwach obywatele sa bardziej chronieni przed agresja $z$ zewnatrz niż w stanie natury chronione sa jednostki przed wzajemna przemoca wobec siebie. Państwa sa bowiem bardziej odporne na ewentualne ataki ze strony innych państw, a ich odpowiedzi bywaja groźniejsze ze względu na zniszczenia, niż ma to miejsce w przypadku walczących między soba ludzi w stanie natury. Możemy więc powiedzieć, że w perspektywie teoretyków szkoły angielskiej interpretacja Hobbesa brzmi bardziej optymistycznie, niż czynią to współcześni realiści polityczni ${ }^{17}$. W ujęciu tym można wytłumaczyć również, dlaczego rzadziej dochodzi do wojen między państwami, niżby to wynikało $z$ modelu Hobbesowskiego, w ramach którego gdyby państwa działały tak jak jednostki w stanie anarchii, to żadna ich długotrwała aktywność nie byłaby możliwa ${ }^{18}$.

Jednocześnie stworzona przez Hobbesa idea stanu natury jako stanu wojny pozwala nam zastanawiać się nad tym, jakie, jeśli

\footnotetext{
${ }^{16}$ Można to obecnie zaobserwować na przykładzie Rosji, która prowadzi skomplikowana grę z Ukraina, posługując się wojna hybrydowa, a więc rozmywając swoja odpowiedzialność za naruszenie granic suwerennego kraju. Mimo wszystko społeczność międzynarodowa w odpowiedzi na naruszenie przez Rosję reguł współpracy międzynarodowej nakłada na nia różnego rodzaju sankcje.

${ }^{17}$ Zob. np. H. Morgenthau, Polityka między narodami, przekład R. Włoch, Difin, Warszawa 2010.

${ }^{18}$ Zob. również A. Gałganek, Historia teorii stosunków międzynarodowych, Wydawnictwo Naukowe PWN, Warszawa 2009, s. 219-239.
} 
w ogóle, normatywne zasady w stosunkach międzynarodowych powinny obowiązywać oraz czym powinny się kierować państwa w tworzeniu reguł międzynarodowej współpracy. Jeśli chodzi o uzasadnienie form współpracy, to podstawa uprawomocnienia staje się interes własny państw. Zatem te reguły, które leżą w interesie wszystkich państw, można uznać za zasady sprawiedliwości $\mathrm{w}$ prawie międzynarodowym. $Z$ pewnościa jest to reguła nienaruszalności terytorialnej, ale również reguły wojny sprawiedliwej, których przestrzeganie przez państwa w perspektywie realizmu politycznego można wytłumaczyć idea interesu własnego oraz idea wzajemnej równowagi sił. Choć więc nie ma światowego suwerena, to istnieja, w społeczności międzynarodowej państw, przestrzegane co do zasady, korzystne dla wszystkich graczy, praktyki - będące odpowiednikiem Hobbesowskich praw natury. Suwerenna władza nie tylko bowiem reguluje czy też kształtuje (Hobbes mówi o formatowaniu) zachowania obywateli, ale musi również zabezpieczać ich wytwory przed niebezpieczeństwem choćby grabieży ze strony innych państw ${ }^{19}$. Lewiatan dokonuje tego zabezpieczenia właśnie dzięki gotowości do wojny obronnej.

W ten oto sposób idea Grocjusza dotycząca społeczności międzynarodowej pozwala szkole angielskiej zreinterpretować Hobbesa stan wojny między państwami jako stan możliwy do regulowania i nie tak anarchistyczny, jak opisuja go przedstawiciele realizmu politycznego. Kluczowe jest tu, zdaniem teoretyków szkoły angielskiej zrozumienie relacji między państwami. Według Bulla, społeczność międzynarodowa „istnieje, kiedy grupa państw, świadoma pewnych wspólnych interesów i wspólnych wartości, tworzy społeczeństwo, w takim znaczeniu, że postrzega sama siebie jako powiązana podzielanymi przez siebie zasadami i udziałem we wspólnych instytucjach"20. Zatem gdy państwa uznaja pewne wspólne interesy i działaja według wzajemnie uznanych zasad, takich jak dotrzymywanie umów, to działają w strukturze społeczności mię-

${ }_{19}$ T. Hobbes, Lewiatan..., s. 112.

${ }^{20}$ H. Bull, The Anarchical Society..., s. 13. 
dzynarodowej. $Z$ perspektywy tradycji grocjuszowskiej opis Hobbesowskich stosunków międzynarodowych interpretowany jest więc jako taki, w którym można ograniczyć przemoc poprzez uznanie, że państwa minimalizuja wzajemne konflikty, akceptując wspólne zasady. Oznacza to, że w świetle rozważań Grocjusza Hobbesowska realistyczna interpretacja stosunków międzynarodowych traci swoje jednowymiarowe, konfliktowe oblicze stanu wojny i przemocy, a stosunki międzynarodowe nie sprowadzaja się tu jedynie do konfliktu interesów między państwami. Nie jest to zarazem teoria, która popada w druga, Kantowska skrajność, i głosi ostateczna zgodność oraz harmonijne współżycie wszystkich państw oraz ludzi w ramach Ligii narodów ${ }^{21}$. Jest to raczej teoria sytuująca się pomiędzy tymi dwoma skrajnymi stanowiskami i głoszaca ich splot. Zasadnicza różnica ujęcia relacji międzynarodowych w szkole angielskiej, od ujęcia Hobbesowskiego, sprowadza się zatem do tego, że państwa zawieraja ze sobą umowy nie tylko ze względu na interes własny (pragmatyczna rozwaga), ale również ze względu na postępowanie zgodne $z$ wymogami moralnymi - prawami natury - co do których sa one w stanie dojść do porozumienia, wspólnie je podzielać i działać według nich. Wymogi te zaś dotycza pokojowej koegzystencji państw. Państwa, kierując się więc własnym dobrem, realizuja zarazem dobro wspólne, ponieważ dostrzegaja, że ich interesy wzajemnie harmonizują.

W perspektywie szkoły angielskiej Hobbesowska przemoc w stosunkach międzynarodowych zostaje tym samym ujęta i zrozumiana jako środek do osiagnięcia celu - bezpieczeństwa państwa - co oznacza, że jest traktowana jako narzędzie przywracania równowagi na poziomie międzynarodowym. Szkoła angielska uznaje jednocześnie, za Grocjuszem, że stan wojny i anarchii w relacjach między państwami nie jest czymś podstawowym, a jedynie pewna możliwościa, która jest regulowana i minimalizowana przez wzajemnie akceptowane reguły gry. Anarchia nie jest więc rozumiana

${ }^{21}$ Zob. I. Kant, Do wiecznego pokoju, w: idem, O porzekadle, to może być słuszne $w$ teorii, ale nic nie jest warte $w$ praktyce, przekład M. Żelazny, Comer, Torun 1995. 
przez szkołę angielska jako stan potencjalnej wojny, ale raczej jako brak nadrzędnego suwerena i stan, w którym poszukuje się regulacji premiujących pokój ${ }^{22}$. Wychodząc $z$ tego założenia, szkoła angielska dowodzi (szukajac potwierdzenia w badaniach empirycznych i studiach historycznych ${ }^{23}$ ), że trwalsze gwarancje pokoju uzyskujemy w systemie pluralistycznej międzynarodowej anarchii, gdzie państwa współpracują ze sobą, niż w systemie międzynarodowym $z$ państwowymi graczami hegemonami, którzy walczą o dominacje i rywalizuja o to, które $z$ nich narzuci swoje prawa innym ${ }^{24}$.

\section{Trafność interpretacji szkoły angielskiej - prawa natury a miecz wladzy}

Mimo wszystko można się zastanawiać, czy szkoła angielska nie akcentuje jednak zbyt jednostronnie i nazbyt optymistycznie teorii Hobbesa, odrzucając zawarte w niej element siły i przemocy. W teorii Hobbesa jest przecież tak, że prawa natury w stanie natury nie sa same $z$ siebie wystarczajace do zagwarantowania pokoju. Jak pisze Hobbes: „[...] Prawo narodów i prawo natury to rzecz ta sama. I każdy suweren ma to samo uprawnienie, gdy chodzi o zabezpieczenie jego narodu, jakie może mieć każdy człowiek poszczególny, gdy chodzi o zabezpieczenie jego własnego ciała"25. Wynikałoby $z$ tego, że suwereni między soba działaja tak samo jak jednostki w stanie natury. Hobbes jednak nie postuluje światowej umowy społecznej, która ten stan potencjalnej wojny między państwami mogłaby przezwyciężyć. Aby taka ugoda była możli-

\footnotetext{
${ }^{22}$ Odwołując się do powiedzenia Wendta, można stwierdzić, że anarchia jest tym, czym czynia ja państwa. Zob. A. Wendt, Społeczna teoria stosunków międzynarodowych, przekład W. Derczyński, Wydawnictwo Naukowe Scholar, Warszawa 2008, s. 47.

${ }^{23}$ Zob. B. Buzan, R. Little, Systemy międzynarodowe w historii świata, przekład E. Brzozowska, Wydawnictwo Naukowe PWN, Warszawa 2011.

${ }^{24}$ Bull uznaje, że to nie idee Hobbesa, ale Grocjusza idea społeczności międzynarodowej ufundowała ład westfalski. Podstawowa idea tego porozumienia opiera się na uznaniu przez państwa zasad wiązących ich wzajemne relacje, takich jak nienaruszalność terytorialna, które podtrzymują społeczność międzynarodową w stabilnej równowadze.

${ }^{25}$ T. Hobbes, Lewiatan..., s. 315.
} 
wa, potrzebna jest bowiem siła, która wszystkie państwa utrzyma w strachu, a więc państwo światowe. Taka światowa umowa wymagałaby od ludzi zgody, a oni przecież już wcześniej zgodzili się na życie w różnych państwach. Hobbes zatem wyklucza możliwość zaistnienia państwa światowego, a tym samym uznanie, że stan anarchii jest stanem wojny między państwami. Czyżby więc szkoła angielska myliła się w swojej interpretacji Hobbesa?

Interpretacji szkoły angielskiej nie daje się jednak wcale tak prosto i łatwo odrzucić, ponieważ sam Hobbes opisuje stan anarchii jako stan potencjalnej, a niekoniecznie realnej wojny, wskazując zaś zadania dla suwerena, uznaje, że jego celem jest dobro obywateli. Dobro to rozumie Hobbes jako ochronę obywateli przed wrogiem zewnętrznym, zapewnienie pokoju wewnętrznego oraz umożliwienie obywatelom prowadzenia działalności gospodarczej26. To właśnie $\mathrm{w}$ imię tych wartości $\mathrm{w}$ interesie suwerena leży prowadzenie pokojowej polityki międzynarodowej, które pozwala na obniżenie ryzyka wojny. Oczywiście państwa maja armie, ponieważ w ramach założeń Hobbesa nie moga one bezgranicznie ufać innym państwom, a więc nie moga pozbawić się środków do własnej obrony, ale jednocześnie użycie armii powinno służyć celom obronnym w imię przywrócenia praw natury albo ukarania tych, którzy je naruszyli.

Co więcej, w swoich rozważaniach o stosunkach międzynarodowych Hobbes nie ogranicza się jedynie do analizy roli armii i rozwiązań siłowych. Poza utrzymywaniem armii i wywiadem Hobbes postuluje również współpracę handlowa między państwami, która zwiększa wzajemne bezpieczeństwo, a także dyplomację, która ma rozwiazywać ewentualne kwestie sporne na drodze pokojowych negocjacji. Uznaje również, że „ligi między państwami [...] sa nie tylko zgodne $z$ prawem, lecz również pożyteczne w tym czasie, kiedy trwaja”" ${ }^{27}$. Choć więc tylko suweren w najbardziej efektywny sposób gwarantuje stan bez przemocy i wojny, a takiego globalnego

${ }^{26}$ Ibidem, s. 152.

${ }^{27}$ Ibidem, s. 210. 
suwerena nie ma w stosunkach międzynarodowych, to $\mathrm{w}$ teorii Hobbesa istnieja elementy zmniejszajace niebezpieczeństwo przemocy między państwami i sprzyjające postępowi, które sam autor Lewiatana uważa za istotne. Postęp w ujęciu Hobbesa nie oznacza jednak, jak u Kanta, ciagłego polepszania prawa, ale pozytywne zmiany przerywane momentami wojen i regresów. Hobbes wskazuje także na postęp zachodzący w stosunkach między państwami i w ich wzajemnych regulacjach, takich jak ograniczenie piractwa, i uznaje, że jest on możliwy dzięki rozumowi ludzkiemu oraz korzyściom płynącym ze współpracy państw. Jego zdaniem, ludzie moga nawet „znaleźć przez pilne rozmyślanie zasady rozumu, na których podstawie będą mogli uczynić swój ustrój państwowy wiecznie trwałym" 28 . Te zasady to sa oczywiście prawa natury, które powinny być podstawą prawa międzynarodowego. Choć zatem miecz władzy jest niezbędny w relacjach wewnątrzpaństwowych, by zabezpieczyć obowiąujące prawa, to nie musi być czymś niezbędnym w relacjach między państwami, by unikać wojen $\mathrm{i}$ by suwerenne państwa działały $\mathrm{w}$ zgodzie $\mathrm{z}$ przyjętymi przez siebie regułami.

Podsumowując nasze dotychczasowe rozważania, możemy powiedzieć, że szkoła angielska sprzeciwia się stanowisku, że Hobbesowska teoria moralna, przynajmniej w kwestii wojny, zakłada polityczny realizm - to znaczy postuluje, że relacje międzynarodowe oraz działania wojenne w ogóle nie moga być oceniane w kategoriach moralnych, ponieważ znajduja się całkowicie poza ich obrębem. W ujęciu Hobbesa dzieje się tak dlatego, ponieważ do wojny dochodzi pomiędzy państwami występującymi przeciwko sobie w stanie natury, w którym nie ma żadnej władzy wyższej zdolnej zmusić je do przestrzegania reguł wzajemnego ograniczania się. Ponadto, według Hobbesa, moralność tworzy się wtedy, gdy ludzie zawieraja umowę, by przejść pod władzę suwerena, a zatem nie stosuje się ona do stanu natury, który jest stanem między państwami.

${ }^{28}$ Ibidem, s. 299. 
Jak staraliśmy się jednak pokazać, można argumentować, tak jak to czyni szkoła angielska, że stosunki międzynarodowe sprzyjaja pokojowi, gdy spełniaja Hobbesowskie prawa natury, oraz że w praktyce państwa moga działać według tych praw bez globalnej władzy zwierzchniej, nawet w ramach założeń przyjętych przez samego Hobbesa. Jest to możliwe, ponieważ wydaje się, że nawet w modelu Hobbesa państwa skłonne sa co do zasady do przestrzegania we wzajemnych relacjach praw natury, ze względu na korzyści, jakie dzięki temu uzyskuja, czyli ze względu na zapewnienie bezpieczeństwa własnym obywatelom. Przemoc w postaci użycia armii $z$ tej perspektywy staje się jedynie środkiem odstraszajacym potencjalnych agresorów albo narzędziem, by bronić się przed wrogiem, który naruszył reguły współpracy międzynarodowej.

Aby wojna i przemoc były zatem uzasadnione, muszą wynikać przynajmniej z pragnienia uniknięcia poważnej krzywdy, a nie tylko $z$ pragnienia suwerena do pomnożenia bogactwa danego kraju czy zapewnienia sobie korzyści przez najazd na obce terytorium. Ludzka chęć osiagnięcia porozumienia $z$ potencjalnymi wrogami o wzajemnym przestrzeganiu reguł gry, do których należałoby unikanie wojen (a gdy jednak takowe wybuchna, to przyzwoite wzajemne na wojnie postępowanie, takie jak wcześniej wspominane niewalczenie $z$ cywilami lub niezabijanie jeńców), wydaje się więc racjonalne i możliwe do zaakceptowania przez wszystkie strony.

Jednocześnie Hobbes, uznając zasadę zachowania życia jako podstawowa, nie może, nie negując przyjętych przez siebie przesłanek, uznawać, że ludzie powinni narażać własne życie w wojnach, do których nakłania ich suweren. Celem państwa, jak pisaliśmy wcześniej, jest bowiem zapewnienie obywatelom stanu pokoju i zmniejszenie ich strachu przed śmiercią. Choć więc suweren ma w teorii Hobbesa władzę absolutna, to ze względu na ten cel powinien on tak kierować swoja polityka wewnętrzną i zewnętrzną, by ludzie nie odmówili mu poparcia i widzieli, że stoi on na straży państwa jako stanu zapewniającego bezpieczeństwo. Tak więc $\mathrm{w}$ interesie samego suwerena leży postępowanie zgodnie $z$ od- 
krytymi przez rozum prawami natury, co przekłada się na arenie międzynarodowej na szukanie sojuszy, zawieranie $z$ innymi państwami układów o nieagresji oraz tworzenie takich reguł i praktyk w stosunkach międzynarodowych, które zwiększaja prawdopodobieństwo pokojowej współpracy $z$ innymi państwami, a $\mathrm{w}$ razie wojny redukuja dowolność prowadzenia działań wojennych przez wszystkie strony konfliktu.

Według Hobbesa ufundowane w ten sposób praktyki bazuja na tym, na co mogliby się racjonalnie zgodzić ludzie dbający o własne interesy. Oczywiście powstałe $\mathrm{w}$ ten sposób prawo lub reguły $\mathrm{w}$ stosunkach międzynarodowych nie maja zabezpieczenia $\mathrm{w}$ postaci miecza władzy, a jedynie $\mathrm{w}$ postaci dobrowolnego (a więc zawsze uznaniowego) przestrzegania reguł prawa międzynarodowego. Niemniej jednak w praktyce takie działania prowadzą do dość stabilnego stanu anarchii, który nie jest takim samym stanem wojny jak ten w stanie natury między jednostkami. Można więc na zakończenie powiedzieć, że choć wspólnota międzynarodowa nie dysponuje żadnymi porównywalnymi środkami, jeśli chodzi o skuteczność dotycząca przestrzegania umów międzynarodowych, w stosunku do tych, którymi w modelu Hobbesa dysponuje suweren wobec swoich poddanych, by przestrzegali oni prawa, to kieruje się ona w podtrzymywaniu współpracy racjonalnością długoterminowej współpracy. Skutecznym zaś bodźcem do jej kontynuowania jest bezpieczeństwo własnych obywateli. Co więcej, jeśli dla suwerenów byłoby czymś uzasadnionym wzajemne przestrzeganie określonych reguł współpracy, to mogłoby to wystarczyć, w Hobbesowskim ujęciu, do uznania tych reguł za reguły moralne rzadzace współdziałaniem państw w czasie pokoju oraz przebiegiem wojen $\mathrm{w}$ trakcie ich trwania. Uznanie powyższego rozumowania prowadziłoby nas tym samym do bronionego w tym artykule stanowiska, że model Hobbesa daje się przynajmniej częściowo zreinterpretować i wpisać w model Grocjusza, który wydaje się lepiej niż model Hobbesowski tłumaczyć brak permanentnej wojny w stosunkach międzynarodowych, a także współpracę między państwami. 